\title{
Pengaruh Supervisi Akademik Kepala Sekolah dan Lingkungan Kerja Terhadap Kinerja Guru Sekolah Dasar Negeri Air Salek
}

\author{
Pujianto $^{1 凶}$, Yasir Arafat $^{2}$, Andi Arif Setiawan ${ }^{3}$ \\ (1) Sekolah Dasar Negeri 18 Air Salek \\ $(2,3)$ Universitas PGRI Palembang
}

$\triangle$ Corresponding author [antop3277@gmail.com]

\begin{abstract}
Abstrak
Penelitian ini bertujuan untuk mengetahui pengaruh supervisi akademik kepala sekolah dan lingkungan kerja terhadap kinerja guru. Penelitian ini menggunakan metode kuantitatif dengan jenis penelitian korelasional. Populasi penelitian sebanyak 30 orang yaitu guru-guru Sekolah Dasar Negeri jalur 8 Kecamatan Air Salek Kabupaten Banyuasin. Teknik pengumpulan data menggunakan kuesioner. Data dianalisis menggunakan teknik analisis korelasi dan regresi ganda. Hasil penelitian menunjukkan bahwa: (1) supervisi akademik kepala sekolah berpengaruh positif dan signifikan terhadap kinerja guru Sekolah Dasar Negeri Jalur 8 Air Salek Banyuasin; (2) Lingkungan kerja berpengaruh positif dan signifikan terhadap kinerja guru Sekolah Dasar Negeri Jalur 8 Air Salek Banyuasin, dan (3) supervisi akademik kepala sekolah dan lingkungan kerja secara bersama-sama berpengaruh positif dan signifikan terhadap kinerja guru Sekolah Dasar Negeri Jalur 8 Air Salek Banyuasin.
\end{abstract}

Kata Kunci: Supervisi Akademik Kepala Sekolah; Lingkungan Kerja,; Kinerja Guru.

\begin{abstract}
This study determined the effect of principals academic supervision and work environment on teacher performance. This Study was conducted aat an elementary school of Air Salek, at the area of Banyuasin. The design of this study is quantitative with correlations methode. The research population was 30 teachers of State Elementary Schools in Lane 8 Air Salek District, Banyuasin Regency. The results showed that: (1) the academic supervision of school principals had a positive and significant effect on the performance of Air Salek Banyuasin 8th Elementary School teachers; (2) The work environment has a positive and significant effect on the performance of teachers at Air Salek Banyuasin 8th Elementary School, and (3) the academic supervision of the school principal and work environment jointly has a positive and significant effect on the performance of teachers at the 8th Air Elementary School in Air Salek, Banyuasin.
\end{abstract}

\section{Keyword: Academic Supervision, Work Environment, Teacher's Performance}

\section{PENDAHULUAN}

Banyaknya guru yang kurang menguasai berbagai kompetensi dan rendahnya profesionalitas guru merupakan hambatan yang dihadapi oleh guru ketika melaksanakan strategi pembelajaran di kelas. Sudah selayaknya, guru harus dapat meningkatkan penguasaan terhadap berbagai kompetensi yang dimilikinya dalam proses pembelajaran di kelas agar melalui peningkatan kompetensi tersebut tercipta kondisi pembelajaran yang dapat menarik minat siswa dalam belajar. Kurangnya minat siswa dalam belajar diakibatkan oleh kurangnya kemampuan guru dalam memanfaatkan metode pembelajaran yang beragam. Guru harus dapat menarik minat siswa dalam proses pembelajaran, menciptakan suasana kelas yang menarik dan tidak membosankan melalui penggunaan berbagai metode pembelajaran yang menarik.

Kurangnya kemampuan seorang guru dalam menggunakan berbagai metode pembelajaran yang menarik bagi siswa, di sinilah peran kepala sekolah diharapkan melaksanakan supervise akademik dengan baik. Menurut Sahertian (2000) supervisi merupakan usaha untuk mengembangkan proses pengajaran ke arah yang lebih baik dengan pemberian bantuan dan layanan bagi guru-guru secara perorangan ataupun per kelompok. Supervisi merupakan upaya dalam rangka mengembangkan profesionalisme guru. Dengan adanya kepala sekolah yang profesional, yang memberikan bantuan kepada guru dengan melaksanakan supervisi kepada guru-gurunya, agar proses pembelajaran di kelas dapat berlangsung lebih baik lagi, akhirnya akan berpengaruh positif bagi pengembangan mutu pendidikan ke arah yang lebih baik lagi (Fathurrohman, 2011). 
Amanda, Salam, \& Saggaf, (2017) melalui hasil penelitiannya dengan judul Pengaruh Supervisi Kepala Sekolah Terhadap Kinerja Guru di Sekolah Menengah Kejuruan Negeri 1 Bungoro Kabupaten Pangkep menyatakan bahwa supervisi yang dilakukan oleh kepala sekolah dapat mengembangkan hasil kerja guru menjadi lebih baiik. Peningkatan hasil kerja guru tersebut juga dapat mempengaruhi keberhasilan siswa dalam belajar. Karena hasil kerja guru tampak dari keberhasilan yang dicapai oleh peserta didik secara akademik maupun non akademik.

Menurut Purbasari, (2015) dalam hasil penelitiannya menyatakan bahwa supervisi akademik yang dilaksanakan oleh kepala sekolah dapat berpengaruh terhadap meningkatnya kinerja guru dalam proses pembelajaran. Kemudian penelitian Hasanah dan Kristiawan (2019) menemukan besarnya pengaruh yang diberikan oleh supervisi akademik kepala sekolah terhadap kinerja guru adalah 5,94 \% dan 94,06\% dipengaruhi oleh faktor lain. Selanjutnya hasil penelitian Ramadona dan Wibowo (2016) menemukan bahwa supervisi kepala sekolah memberikan kontribusi pengaruh dalam pening katan kinerjaguru sebesar 49,63\% sedangkan sisanya 50,37\% dipengaruhi oleh faktor-faktor lain.

Kepala sekolah adalah seseorang yang dijadikan contoh dan panutan bagi para guru dan peserta didik dalam pembentukan karakter baik dalam hal kedisiplinan, maupun dalam hal etika dan moral. Pernyataan ini juga didukung dengan penerapan kurikulum baru yang ber orientasi pada pembentukan karakter siswa. Memberikan pengetahuan tentang etika pergaulan, penanaman nilai-nilai agama, moral, budi pekerti serta etika bagi anak didik, harus di lakukan secara berkesinambungan.

Peran kepala sekolah dalam meningkatkan kinerja guru adalah salah satu unsur pendidikan yang sangat berpengaruh. Penyelenggaraan kegiatan pendidikan, administrasi sekolah, pembinaan tenaga lainnya, dan pendayagunaan serta pemeliharaan sarana dan prasarana merupakan tanggung jawab kepala sekolah. Beberapa keadaan yang masih sering menjadi masalah dalam lembaga pendidikan di antaranya adalah beberapa guru ada yang masih kurang memiliki kedisiplinan dalam melaksanakan tugas, datang ter lambat namun pulang lebih awal, merupakan akibat dari krang maksimalnya pembinaan dan bimbingan dari kepala sekolah terhadap guru-guru.

Tugas dan peran kepala sekolah yaitu memberikan panduan, tuntunan, bimbingan, membangun, dan memberikan memberi motivasi kerja, menjalankan organisasi, menjalin jaringan komunikasi yang baik, memberi supervisi atau pengawasan yang efisien berdasarkan ketentuan waktu dan perencanaan (Sutomo, 2006).

Menurut Suhardiman (2012) kompetensi kepala sekolah yaitu kompetensi kepribadian, kompetensi manajerial, kompetensi kewirausahaan, kompetensi supervisi, dan kompetensi sosial. Senada dengan yang dikemukakan oleh Suhardiman (2012), maka sudah menjadi kewajiban kepala sekolah sebagai supervisor untuk memberikn bimbingan kepada guru dalam melaksanakan proses pembelajaran melalui supervisi akademik. Menurut Pidarta (2009) posisi kepala sekolah sebagai supervisor memiliki tugas untuk membina para guru menjadi profesional. Pembinaan terhadap guru meliputi aspek pribadi guru, peningkatan profesi yang terus menerus, pembinaan untuk memperbaiki kekurangan dalam proses pembelajaran, penguasaan materi pelajaran, pembinaan berkenaan dengan keragaman kemampuan guru, keragaman daerah, serta kemampuan guru dalam kerja sama dengan masyarakat.

Masalah lain yang dapat mempengaruhi kinerja guru selain supervisi akademik adalah lingkungan kerja. Nitisemito (2001) menyatakan bahwa lingkungan kerja merupakan semua yang ada di sekitar pekerja yang merupakan salah satu faktor yang berpengaruh bagi pekerja dalam melaksanakan tugas-tugas dan kewajibannya. Dengan adanya lingkungan kerja yang baik, guru akan dapat menjalankan tugasnya dengan baik juga. Adanya lingkungan kerja yang sehat, nyaman, dan kondusif akan apat mengembangkan produktivitas guru yang pada akhirnya dapat menghasilkan kinerja guru yang lebih baik.

\section{METODE PENELITIAN}

Penelitian ini dilaksanakan di Sekolah Dasar Negeri jalur 8 kecamatan Air Salek Kabupaten Banyuasin, terdiri dari 4 Sekolah Dasar Negeri yaitu, Sekolah Dasar Negeri 11 Air Salek, Sekolah Dasar Negeri 15 Air Salek, Sekolah Dasar Negeri 18 Air salek, dan Sekolah Dasar Negeri 22 Air Salek. Penelitian ini dilaksanakan pada bulan Maret 2020 sampai dengan Juni 2020. Pelaksanaan penelitian terbagi menjadi beberapa tahapan yaitu: tahap persiapan, tahap penyusunan proposal, tahap seminar proposal, tahap perbaikan proposal, tahap pelaksanaan penelitian, tahap pengumpulan data, tahap pengolahan data, dan tahap penyusunan laporan.

Metode penelitian yang digunakan dalam penelitian ini adalah ex-post- facto. Arikunto (2010) mengatakan bahwa penelitian ex-post- facto adalah model penelitian yang kejadiannya sudah terjadi sebelum penelitian dilaksanakan. Penelitian ex-post- facto hanya mengungkap gejalagejala yang ada dan telah terjadi sebelumnya, sehingga dalam penelitian ini tidak perlu memberikan perlakuan terhadap variabel dalam penelitian. Pendekatan yang digunakan dalam penelitian ini menggunakan pendekatan kuantitatif, karena data yang diperoleh akan diwujudkan dalam bentuk angka dan dianalisis berdasarkan statistik. Menurut Sugiyono (2012), pendekatan kuantitatif digunakan untuk meneliti populasi atau sampel penelitiantertentu dengan menggunakan teknik pengambilan sampel yang dilakukan secara acak. 
Arikunto (2006) mengatakan bahwa populasi adalah jumlah keseluruhan subjek penelitian. Penelitian ini yang menjadi subjek penelitian adalah seluruh guru Sekolah Dasar Negeri se-Jalur 8 kecamata Air Salek Kabupaten Banyuasin yang berjumlah empat sekolah. Jumlah guru yang dijadikan populasi sebanyak 30 orang dari hasil rekapitulasi akhir tahun pelajaran 2019/2020. Penelitian ini mengambil seluruh populasi sebagai sampel, sehingga penelitian ini merupakan penelitian populasi.

Teknik pengumpulan data dalam penelitian ini menggunakan metode kuesioner. Kuesioner merupakan teknik pengumpulan data yang dilakukan dengan cara memberi seperangkat pertanyaan atau pernyataan kepada responden untuk dijawabnya. Kuesioner yang digunakan adalah model kuesioner tertutup yaitu kuesioner yang jawabannya sudah disediakan oleh peneliti sehingga responden tinggal memilih. Metode kuesioner digunakan untuk memperoleh data supervisi akademik kepala sekolah, lingkungan kerja, dan kinerja guru.

\section{HASIL PENELITIAN DAN PEMBAHASAN}

Penelitian ini bertujuan untuk menganalisis Pengaruh supervisi akademik kepala sekolah dan lingkungan kerja terhadap kinerja guru Sekolah Dasar Negeri se-Jalur 8 Kecamatan Air Salek Kabupaten Banyuasin, Propinsi Sumatera Selatan. Penelitian ini dilakukan pada bulan Maret sampai dengan Juni terhadap 30 guru Sekolah Dasar se-Jalur 8 Kecamatan Air Salek Kabupaten Banyuasin. Sebelum dilakukan penelitian terhadap sampel penelitian, dilakukan uji coba instrumen penelitian terhadap 30 sampel uji coba di luar sampel penelitian. Selanjutnya, untuk memperoleh butir pernyataan yang valid dan reliabel, dilakukan uji validitas dan uji reliabilitas terhadap hasil pengisian kuesioner dari uji coba instrumen tersebut. Setelah instrumen penelitian dinyatakan valid dan reliable, kuesioner penelitian dibagikan kepada responden yang terdiri 30 orang guru Sekolah Dasar Negeri se-jalur 8 kecamatan Air Salek Kabupaten Banyuasin.

Responden pada penelitian ini berjumlah 30 orang yang merupakan guru Sekolah Dasar Negeri se-jalur 8 kecamatan Air Salek Kabupaten Banyuasin. Berikut merupakan deskripsi subjek berdasarkan jenis kelamin, usia, pendidikan terakhir, status pernikahan, dan masa kerja.

Tabel 1 Deskripsi Jenis Kelamin Responden Penelitian

\begin{tabular}{lcc}
\hline Jenis Kelamin & $\begin{array}{c}\text { Frekuens } \\
\mathbf{i}\end{array}$ & Persentase \\
\hline Perempuan & 15 & $50 \%$ \\
\hline Laki-laki & 15 & $50 \%$ \\
\hline Total & 30 & $100 \%$ \\
\hline
\end{tabular}

Tabel 1 menunjukkan bahwa jenis kelamin dari responden penelitian sama banyak antara laki-laki dan perempuan yaitu 15 laki-laki dan 15 perempuan. Putri (2016) dalam penelitiannya menyatakan faktor jenis kelamin ikut menentukan tingkat partisipasi dan produktivitas seseorang dalam bekerja. Pegawai pada dasarnya tidak dapat dibedakan berdasarkan pada jenis kelamin. Kenyataannya laki-laki akan lebih produktif untuk pekerjaan yang mengandalkan kekuatan fisik, akan tetapi dalam keadaan tertentu kadang produktivitas perempuan bisa lebih tinggi daripada laki-laki, dikarenakan perempuan lebih teliti, sabar, dan tekun. Berdasarkan dari penelitian putri dan temuan di lapangan maka peneliti menyimpulkan bahwa laki-laki lebih kuat dan lebih produktif dalam bekerja. Akan tetapi dalam hal ketelitian dan kesabaran perempuan lebih teleiti dan sabar bila dibandingkan laki-laki.

Tabel 2 Deskripsi Usia Subjek Penelitian

\begin{tabular}{lcc}
\hline Usia & Frekuensi & Persentase \\
\hline 20-40 Tahun & 21 & $70 \%$ \\
\hline 40-60 Tahun & 9 & $30 \%$ \\
\hline Total & 30 & $100 \%$ \\
\hline
\end{tabular}

Tabel 2 menunjukan bahwa usia guru Sekolah Dasar Negeri yang berada di Air Salek mayoritas masih muda, artinya di usia muda tersebut sangat dimungkinkan untuk meningkatkan kompetensi dan kinerja. Penelitian ini sejalan dengan yang dilakukan Labich (1993) yang menemukan bahwa usia dan kinerja mempunyai hubungan yang positif. Aprilyanti (2017) dalam penelitiannya juga menyatakan usia pegawai yang masih dalam masa produktif biasanya mempunyai tingkat produktivitas lebih tinggi dibandingkan dengan yang sudah berusia tua sehingga fisik yang dimiliki menjadi lemah dan terbatas. Sejalan dengan penelitian di atas dan kenyataan di lapangan maka usia muda sangat dimungkinkan untuk meningkatkan kompetensinya dalam melasanakan pekerjaannya. 
Tabel 3 Deskripsi Pendidikan Terakhir Responden Penelitian

\begin{tabular}{lcc}
\hline Pendidikan Terakhir & Frekuensi & Persentase \\
\hline D3 & 1 & $3,3 \%$ \\
\hline S1 & 29 & $96,7 \%$ \\
\hline Total & 30 & $100 \%$ \\
\hline
\end{tabular}

Tabel 3 menunjukkan bahwa mayoritas pendidikan terakhir guru Sekolah Dasar Negeri yang berada di Air Salek adalah S1. Hal ini menunjukkan bahwa bila dilihat dari latar belakang pendidikan, mayoritas guru Sekolah Dasar Negeri Air Salek memiliki kualitas yang baik. Putri (2016) dalam peneltiannya menyatakan bahwa melalui pendidikan seorang pegawai dapat memiliki keterampilan sehingga lebih terampil dan dengan mudah mampu bekerja serta menggunakan fasilitas kerja dengan baik. Berdasarkan hasil temuan dilapangan dan penelitian putri maka peneliti menyampaikan bahwa latar belakang pendidikan sangat berpengaruh dengan kualitas pekerjaan yang dilakukan oleh seseorang.

\section{Tabel 4 Deskripsi Status Pernikahan Responden Penelitian}

\begin{tabular}{lcc}
\hline Status Pernikahan & Jumlah & Persentase \\
\hline Belum Menikah & 2 & $6,7 \%$ \\
\hline Sudah Menikah & 28 & $93,3 \%$ \\
\hline Total & 30 & $100,0 \%$ \\
\hline
\end{tabular}

Tabel 4 menunjukkan bahwa mayoritas status pernikahan guru Sekolah Dasar Negeri yang berada di Air Salek adalah sudah menikah. Orang yang sudah menikah cenderung juga memiliki komitmen tinggi terhadap pekerjaannya karena memiliki tanggungjawab untuk menafkahi keluarganya sehingga kinerjanya dapat meningkat. Sutanto \& Ratna (2015) dalam penelitiannya menyatakan status pernikahan sebagai bagian dari karakteristik individu pada komitmen organisasional mempunyai hubungan dengan kinerja karyawan. Ketika ketiga komitmen itu mempunyai nilai yang tinggi, kinerja karyawan juga mempunyai nilai yang tinggi. Hal tersebut senada dengan peneliti bahwa orang yang sudah menikah dapat berpikir dengan teliti sehingga dalam menyelesaikan suatu pekerjaan akan mendapatkan hasil yang bagus, walaupun dalam menyelesaikannya butuh waktu agak lama karena kehati-hatiannya.

Tabel 5 Deskripsi Masa Kerja Responden Penelitian

\begin{tabular}{ccc}
\hline Masa Kerja & Jumlah & Persentase \\
\hline$<6$ tahun & 6 & $20.0 \%$ \\
6 - 10 tahun & 11 & $36.7 \%$ \\
$>10$ tahun & 13 & $43.3 \%$ \\
Total & 30 & $100.0 \%$ \\
\hline
\end{tabular}

Tabel 5 menunjukkan bahwa masa kerja guru Sekolah Dasar Negeri yang berada di Air Salek mayoritas lebih dari 10 tahun dan sudah memiliki pengalaman dan keterampilan dalam mengajar yang semakin baik. Aprilyanti (2017) menyatakan semakin lama seorang pegawai bekerja, akan meningkatkan keterampilan dan kemampuan melakukan pekerjaannya. Meningkatnya kemampuan dan ketrampilan karena kedewasaan teknis seseorang sehingga akan meningkat pula pengalamannya dalam melaksanakan pekerjaan secara terus menerus. Peneliti juga sependapat bahwa masa kerja yang lama cenderung untuk dapat meningkatkan ketrampilan dan kemempuannya dalam melalukan pekerjaan.

Supervisi akademik kepala sekolah pada penelitian ini adalah semua bentuk bantuan dari kepala Sekolah Dasar Negeri se-Jalur 8 kecamatan Air Salek Kabupaten Banyuasin yang bertujuan untuk mengembangkan kemampuan para guru dalam melakukan pekerjaan mereka secara efektif yang lebih merupakan upaya untuk memberikan bimbingan, dorongan, dan pengayoman untuk dapat terus meningkatkan mutu pendidikan maupun pelayanannya.

Hasil penelitian ini menemukan bahwa Hipotesis H01 ditolak dan Hipotesis Ha1 diterima atau dengan kata lain, variabel supervisi akademik kepala sekolah secara parsial berpengaruh terhadap kinerja guru Sekolah Dasar Negeri se-Jalur 8 kecamatan Air Salek Kabupaten Banyuasin. Artinya, jika kualitas supervisi akademik kepala sekolah ditingkatkan maka kinerja guru juga akan meningkat dan sebaliknya jika kualitas supervisi akademik kepala sekolah menurun, maka kinerja guru juga akan menurun.

Supervisi akademik kepala sekolah pada penelitian ini diukur berdasarkan pendapat responden tentang perencanaan program supervisi akademik, pelaksanaan supervisi akademik, dan evaluasi hasil supervisi akademik oleh kepala sekolah. Dengan demikian, supervisi akademik kepala sekolah yang ditunjukkan dari 
indikator perencanaan supervisi akademik kepala sekolah, pelaksanaan supervisi akademik kepala sekolah, dan evaluasi supervisi akademik kepala sekolah pada Sekolah Dasar Negeri se-Jalur 8 kecamatan Air Salek Kabupaten Banyuasin meningkat akan diikuti dengan meningkatnya kinerja guru dan sebaliknya jika supervisi akademik kepala sekolah menurun, akan diikuti dengan menurunnya kinerja guru-guru secara signifikan.

Indikator perencanaan supervisi akademik menunjukkan, kepala sekolah pada Sekolah Dasar Negeri se-Jalur 8 kecamatan Air Salek Kabupaten Banyuasin harus mampu merencanakan supervisi akademik dengan memperhatikan aspek - aspek yang mendukung perencanaan supervisi akademik. Pada tahap persiapan supervisi hendaknya kepala sekolah menampilkan tujuan dan sasaran dalam melaksanakan supervisi, penyusunan jadwal/waktu melaksanakan supervisi, perencanaan teknik dan langkah dalam melaksanakan supervisi akademik.

Indikator pelaksanaan menunjukkan bahwa pada serangkaian supervisi akademik yang disebut juga tahap pengamatan adalah kepala sekolah mengetahui pelaksanaan kegiatan pembelajaran yang dilakukan oleh guru. Pelaksanaan supervisi hendaknya dilakukan secara berkesinambungan, agar kepala sekolah dapat memonitoring dengan baik atas kinerja guru dalam melaksanakan kegiatan pembelajaran. Pernyataan ini berkaitan pula dengan upaya meningkatkan kinerja guru dalam pembelajaran.

Hasil analisis deskriptif juga menemukan responden menyatakan setuju terhadap pernyataan kuesioner penelitian pada variabel supervisi akademik kepala sekolah, walaupun pada awalnya peneliti menemukan sebagian dari kepala sekolah belum melaksanakan supervisi secara terprogram, akan tetapi peneliti juga menemukan dari sebagian kepala sekolah yang sudah melaksanakan supervisi secara rutin dengan jadwal yang sudah dibuat. Dengan demikian peneliti dapat menyimpulkan bahwa bagi kepala sekolah yang melaksanakan supervisi akademik secara kontinu maka kinerja guru dapat meningkat. Sehingga dengan kata lain dapat dikatakan bahwa Supervisi Akademik sangat berpengaruh terhadap kinerja guru Sekolah Dasar Negeri se-Jalur 8 kecamatan Air Salek Kabupaten Banyuasin. Sebagian besar dari responden memberikan tanggapan yang baik tentang pengaruh supervisi akademik kepala sekolah. Dengan rata-rata skor tanggapan responden terhadap variabel supervisi akademik ialah 4,1 dan berada pada kategori baik. Artinya, secara keseluruhan responden memberikan tanggapan yang baik tentang supervisi akademik kepala Sekolah Dasar Negeri se-Jalur 8 kecamatan Air Salek Kabupaten Banyuasin. Pernyataan Kepala sekolah membuat jadwal kegiatan supervisi akademik memiliki rata-rata skor 4,5 dan merupakan skor pernyataan tertinggi dibanding pernyataan lainnya.

Pernyataan ini menunjukkan bahwa kepala sekolah sudah melakukan perencanaan program supervisi akademik dengan sangat baik terutama pada tahap persiapan supervisi yang tampak dari kesiapan kepala sekolah dalam membuat dan menetapkan jadwal kegiatan supervisi akademik yang disusun setiap awal tahun pembelajaran. Walaupun ada pernyataan yang memiliki rata-rata rendah yaitu 3,6 pada pernyataan memberikan penghargaan kepada guru yang mendapatkan hasil supervisi dengan nilai baik. Hal itu dikarenakan ada sebagian sekolah yang belum melaksanakan supervisi secara rutin. Namun sebagian besar kepala sekolah yang berada di Jalur 8 Kecamatan Air Salek Sudah melaksanakan program supervisi dengan baik sesuai dengan jadwal.

Berdasarkan hasil uji koefisien determinasi diperoleh data 21,3\% dari kinerja guru Sekolah Dasar Negeri se-Jalur 8 Kecamatan Air Salek Kabupaten Banyuasin dapat dijelaskan dengan supervisi akademik kepala sekolah. Dari hasil penelitian ini kepala sekolah sebagai supervisor hendaknya dapat memberikan bimbingan dan pembinaan kepada guru-guru Sekolah Dasar Negeri se-Jalur 8 kecamatan Air Salek Kabupaten Banyuasin agar guru yang profesional. Pemberian bimbingan kepada guru meliputi aspek pribadi guru, peningkatan profesi yang berkelanjutan, pemberian bimbingan untuk memperbaiki kelemahan dalam proses mengajar, penguasaan materi pelajaran, pemberian bimbingan yang berkaitan dengan berbagai macam kemampuan guru, perbedaan daerah, serta kemampuan guru dalam bekerja sama dengan masyarakat sekitar. Pemberian bimbingan yang dilaksanakan oleh kepala sekolah ini dilakukan dalam memberikan bantuan teknis kepada guru dalam melaksanakan tugas mengajar di kelas.

Hasil penelitian ini menemukan bahwa supervisi akademik kepala sekolah menjadi salah satu faktor yang dapat mempengaruhi kinerja guru-guru Sekolah Dasar Negeri se-Jalur 8 kecamatan Air Salek Kabupaten Banyuasin, sehingga kepala sekolah diharapkan dapat melakukan supervisi terhadap guru-guru yang dipimpinnya secara berkala dengan rutin untuk dapat mengembangkan kompetensi guru-guru. Pernyataan ini senada dengan pendapat Purwanto (2012:12) bahwa supervisi merupakan semua bentuk bantuan dari pimpinan sekolah yang bertujuan untuk mengembangkan kepemimpinan para guru dan personel sekolah lainnya di dalam mencapai tujuan pendidikan.

Supervisi ialah suatu kegiatan pembinaan yang direncanakan untuk memberikan bantuan bagi para guru dan pegawai sekolah lainnya untuk melaksanakan pekerjaan mereka secara efektif. Untuk mengembangkan dan meningkatkan proses hasil belajar siswa agar kegiatan pembinaan sesuai dengan peningkatan kemampuan profesional guru supervisi akademik kepala sekolah terhadap guru-guru Sekolah Dasar Negeri se-Jalur 8 Air Salek dilakukan dengan memfokuskan pengawasan supervisor terutama terhadap 
masalah-masalah akademik, yaitu semua hal yang berhubungan dengan lingkungan aktivitas belajar mengajar selama siswa dalam proses mempelajari sesuatu di kelas.

Supervisi perlu dilaksanakan untuk memperoleh kinerja guru yang lebih baik lagi. Bimbingan, arahan dan bantuan dari kepala sekolah akan sangat brpengaruh bagi guru ketika menyelesaikan segala bentuk tugas pengajaran. Supervisi dapat menjadi bahan evaluasi baik bagi guru dan juga bagi kepala sekolah. Hingga pada akhirnya guru dapat mengetahui kinerjanya sudah sesuai dengan tujuan yang diharapkan atau belum.

Pengaruh dari pelaksanaan supervisi akademik terhadap kinerja guru dalam pembelajaran hendaknya dapat menjadi perhatian bagi kepala sekolah, guru, dan juga pihak lain yang berkecimpung dalam bidang pendidikan di Sekolah Dasar Negeri se-Jalur 8 kecamatan Air Salek Kabupaten Banyuasin, agar dapat mewujudkan kinerja guru yang berkualitas yang salah satu caranya melalui pelaksanaan supervisi akademik. Berbagai efek positif yang diharapkan muncul sebagai akibat dari kinerja guru yang berkualitas, diantaranya dengan meningkatnya prestasi belajar siswa, guru yang profesional, serta peningkatan mutu pendidikan di Indonesia dapat tercapai.

Berdasarkan uraian di atas, dapat disimpulkan bahwa supervisi akademik adalah bagian yang sangat krusial dalam pencapaian tujuan pembelajaran. Tujuan supervisi akademik khususnya di Sekolah Dasar Negeri se-Jalur 8 kecamatan Air Salek Kabupaten Banyuasin yaitu memberian pembinaan bagi guru dalam memberikan perbaikan pada proses pembelajaran untuk meningkatkan kualitas dan hasil pembelajaran. Supervisi akademik dibutuhkan kepala sekolah untuk terjun langsung dan melihat bagaimana proses pembelajaran yang terjadi di kelas. Supervisi dalam bentuk pemberian bimbingan dan layanan kepada guru secara langsung diharapkan dapat menjadikan kinerja guru-guru Sekolah Dasar Negeri se-Jalur 8 kecamatan Air Salek Kabupaten Banyuasin dalam proses pembelajaran lebih baik, agar bisa prestasi akademik siswa juga menjadi lebih baik.

Lingkungan kerja pada penelitian ini adalah segala sesuatu yang ada di sekitar guru-guru Sekolah Dasar Negeri se-Jalur 8 kecamatan Air Salek Kabupaten Banyuasin dan dapat memberikan pengaruh bagi mereka dalam menjalankan tugas-tugas yang dibebankan.

Penelitian ini menunjukkan bahwa Hipotesis $\mathrm{HO} 2$ ditolak dan Hipotesis $\mathrm{Ha} 2$ diterima atau dengan kata lain, variabel lingkungan kerja secara parsial berpengaruh terhadap kinerja guru Sekolah Dasar Negeri seJalur 8 kecamatan Air Salek Kabupaten Banyuasin sehingga hal ini berarti, jika kualitas lingkungan kerja ditingkatkan maka kinerja guru juga akan meningkat dan sebaliknya jika kualitas lingkungan kerja di sekolah menurun, maka kinerja guru juga akan menurun. Hasil uji koefisien determinasi diperoleh data $23 \%$ kinerja guru Sekolah Dasar Negeri se-Jalur 8 kecamatan Air Salaek Kabupaten Banyuasin dapat dijelaskan dengan lingkungan kerja.

Hasil analisis deskriptif juga menemukan responden menyatakan sangat setuju terhadap pernyataan kuesioner penelitian pada lingkungan kerja, dengan kata lain guru-guru Sekolah Dasar Negeri se-Jalur 8 kecamatan Air Salek Kabupaten Banyuasin memberikan tanggapan yang sangat baik tentang pengaruh lingkungan kerja. Rata-rata skor tanggapan responden terhadap variabel lingkungan kerja secara keseluruhan berada pada kategori sangat baik dengan rata-rata skor kuesioner 4,6. Artinya, responden memberikan tanggapan yang sangat baik tentang lingkungan kerja. Pernyataan Warna ruangan yang redup membuat saya malas bekerja; Kepala sekolah memberikan kesempatan kepada guru dan karyawan untuk mengikuti kegiatan yang bersifat kedinasan; dan Apresiasi yang positif atas hasil pekerjaan saya dari kepala sekolah menjadi pemicu dalam berprestasi memiliki rata-rata skor 4,70 dan merupakan skor pernyataan tertinggi dibanding pernyataan lainnya. Hasil ini menunjukkan bahwa lingkungan kerja yang ditunjukkan dari indikator lingkungan fisik dan lingkungan sosial meningkat akan diikuti dengan meningkatnya kinerja guru dan sebaliknya jika lingkungan kerja menurun, akan diikuti dengan menurunnya kinerja.

Lingkungan fisik yaitu setiap keadaan berbentuk fisik yang terdapat di sekitar tampat kerja yang memberikan pengaruh terhadap guru baik secara langsung maupun tidak langsung. Lingkungan kerja lebih difokuskan pada keadaan fisik tempat kerja sebab dengan tidak adanya intervensi dalam lingkungan kerja guru bisa melaksanakan tugasnya dengan baik diantaranya kesediaan penerangan, suhu udara, kebersihan, suara bising, penggunaan warna, peralatan kantor, keamanan kerja, ukuran ruangan, kurang ventilasi, tata letak ruangan, musik, keadaan gaduh; dan indikator pada lingkungan sosial yaitu hubungan sesama rekan kerja, hubungan kerja antara kepala sekolah dengan guru-guru Sekolah Dasar Negeri se-Jalur 8 kecamatan Air Salek Kabupaten Banyuasin.

Lingkungan kerja guru-guru Sekolah Dasar Negeri se-Jalur 8 kecamatan Air Salek Kabupaten Banyuasin pada kenyataannya sudah baik. Pada umumnya kondisi lingkungan kerja guru-guru Sekolah Dasar Negeri se-Jalur 8 kecamatan Air Salek Kabupaten Banyuasin sudah nyaman dan tenang walaupun ada sebagian sekolah yang kondisi lingkungan kerjanya tidak nyaman. Lokasi sekolah sebagian besar berada jauh dari jalan raya yang mengakibatkan suasana sekolah tidak bising, tapi ada beberapa sekolah yang berada di dekat jalan raya. Kondisi udara sekolah-sekolah di Kabupaten Banyuasin pada umumnya tidak terlalu panas sehingga kegiatan belajar mengajar berjalan lancar walaupun ada sekolah yang ada di daerah yang udaranya 
panas. Kebersihan di lingkungan sekolah diperhatikan dengan baik karena setiap hari dibersihkan oleh petugas. Sekolah juga selalu aman karena dijaga oleh satpam namun ada juga sekolah yang belum ada satpamnya. Ruang guru di sekolah tertata rapi yang memberi kemudahan pada guru dalam melaksanakan tugasnya. Lingkungan kerja fisik di Sekolah Dasar Negeri se-Jalur 8 kecamatan Air Salek Kabupaten Banyuasin ini dikategorikan sangat baik. Namun masih ada yang berada pada lingkungan yang cukup dan kurang baik.

Lingkungan kerja sosial di Sekolah Dasar Negeri se-Jalur 8 kecamatan Air Salek Kabupaten Banyuasin pada umumnya baik hubungan antara kepala sekolah dan guru terjalin harmonis. Hubungan antar sesama guru dan anggota lainnya di sekolah juga terjalin dengan baik yang akan menambah semangat untuk bekerja sehingga kinerja guru juga meninggkat. Kondisi lingkungan kerja sosial yang ada pada guru-guru Sekolah Dasar Negeri se-Jalur 8 kecamatan Air Salek Kabupaten Banyuasin sudah baik hal ini di tunjukkan dari hasil penelitian bahwa distribusi jawaban responden yang masuk kategori kurang baik dan tidak baik adalah 0 . Guru dapat bekerja dengan baik apabila didukung oleh lingkungan kerja yang baik pula. Umumnya lingkungan kerja di Kabupaten Banyuasin baik sehingga kinerja-kinerja para guru meningkat.

Mutu seorang guru dipengaruhi oleh banyak faktor, baik faktor internal maupun eksternal. Hasil penelitian ini membuktikan bahwa salah satu faktor eksternal yang mempengaruhi kinerja guru adalah lingkungan kerja. Lingkungan kerja yang terjadi di sekolah dapat menunjang kegiatan belajar mengajar, yang meliputi kepemimpinan sekolah, iklim organisasi, keberadaan ruang kerja, sirkulasi udara, model ruangan, kontrasi ruangan, penerangan, posisi pintu dan jendela, penempatan fasilitas kerja, papan tulis dan meja guru, aksesoris, penempatan kursi, penataan media belajar, ketersediaan buku yang berpotensi menunjang pelaksanaan kerja guru-guru Sekolah Dasar Negeri se-Jalur 8 kecamatan Air Salek Kabupaten Banyuasin.

Manfaat lingkungan kerja adalah menciptakan semangat kerja, agar dapat terjadi peningkatan produktivitas dalam bekerja. Manfaat yang diperoleh karena bekerja dengan orang-orang yang termotivasi adalah pekerjaan dapat diselesaikan dengan tepat. Berarti, pekerjaan dapat selesai berdasarkan standar yang benar dan dalam rentang waktu yang ditetapkan. Kinerjanya akan dipantau oleh individu yang bersangkutan dan tidak membutuhkan begitu banyak pengawasan serta semangat juangnya akan tinggi (Arep, 2013).

Lingkungan Kerja Guru dalam keadaan baik dan nyaman akan dapat menjadi inspirasi bagi guru untuk mengembangkan kreativitasnya dalam memberikan pembelajaran pada siswa. Mengacu pada pendapat Torrance dalam Ali dan Asrori (2005), maka lingkungan sekolah adalah lingkungan kerja guru yang dapat memberikan pengaruh terhadap kreativitas guru. Artinya, semakin baik lingkungan kerja maka kinerja guruguru Sekolah Dasar Negeri se-Jalur 8 kecamatan Air Salek Kabupaten Banyuasin dalam Pembelajaran akan semakin meningkat.

Lingkungan kerja guru adalah hal penting yang harus diperhatikan oleh pihak sekolah. Lingkungan di sekitar tempat guru melaksanakan kerjanya tentunya akan memberikan gairah kerja bagi guru dan dapat mempengaruhi dirinya dalam menjalankan tugas-tugas yang dibebankan, misalnya kebersihan, musik, dan lain-lain. Oleh karena itu, lingkungan kerja guru-guru Sekolah Dasar Negeri se-Jalur 8 kecamatan Air Salek Kabupaten Banyuasin harus benar-benar diperhatikan dan diatur sedemikian rupa, sehingga dapat menciptakan suasana nyaman dan menyenangkan yang akan mendorong semangat dalam melaksanakan belajar mengajar dengan lebih giat. Walaupun peneliti menemukan ada sebagian kecil lingkungan kerja guru Sekolah Dasar Negeri Se-Jalur 8 Kecamatan Air Salek Kabupaten Banyuasin belum memadai, akan tetapi frekuensi tanggapan responden memliki rata-rata baik yaitu 4,6. Artinya lingkungan kerja guru Sekolah Dasar Negeri se-Jalur 8 Kecamatan Air Salek Kabupaten Banyuasin dapat mendukung untuk peningkatan kinerja guru.

Kinerja guru pada penelitian ini merupakan kemampuan guru Sekolah Dasar Negeri se-Jalur 8 kecamatan Air Salek Kabupaten Banyuasin dalam melaksanakan tugas pembelajaran di sekolah dan bertanggung jawab atas peserta didik di bawah bimbingannya dengan meningkatkan prestasi belajar peserta didik.

Penelitian ini juga menemukan bahwa Hipotesis $\mathrm{H} 03$ ditolak dan Hipotesis Ha3 diterima atau dengan kata lain, supervisi akademik kepala sekolah dan lingkungan kerja secara bersama-sama berpengaruh terhadap kinerja guru Sekolah Dasar Negeri se-Jalur 8 kecamatan Air Salek Kabupaten Banyuasin. Artinya, jika kualitas supervisi akademik kepala sekolah dan lingkungan kerja meningkat maka kinerja guru juga akan meningkat dan sebaliknya jika kualitas supervisi akademik kepala sekolah dan lingkungan kerja menurun, maka kinerja guru-guru juga akan menurun.

Penelitian ini menunjukkan bahwa supervisi akademik kepala sekolah dan lingkungan kerja guru Sekolah Dasar Negeri se-Jalur 8 kecamatan Air Salek Kabupaten Banyuasin memiliki pengaruh positif terhadap kinerja guru. Supervisi akademik kepala sekolah merupakan semua usaha dari kepala sekolah dalam memimpin guru-guru dan pegawai lainnya dalam memperbaiki pengajaran termasuk menstimulasi, menyeleksi pertumbuhan jabatan dan perkembangan para guru serta memperbiki arah tujuan pendidikan, bahan pengajaran, dan metode serta evaluasi pengajaran. Lingkungan kerja yang kondusif dan positif di Sekolah Dasar Negeri se-Jalur 8 kecamatan Air Salek Kabupaten Banyuasin dapat tercipta jika adanya interaksi yang baik dan harmonis antara kepala sekolah dan guru, guru dengan guru, guru dengan tenaga 
kependidikan, serta peserta didik. Menciptakan lingkungan kerja yang baik tidak hanya melibatkan kepala sekolah saja tapi juga semua warga sekolah harus dapat menciptakan lingkungan kerja yang baik melalui komunikasi antara kepala sekolah dengan guru, guru dengan guru, dan guru dengan siswa. Lingkungan kerja yang baik bisa menciptakan suasana yang nyaman dan keakraban akan tercipta dengan baik. Menciptakan lingkungan kerja yang kondusif, perlu untuk diketahui ada beberapa hal yang harus diperhatikan antara lain lingkungan fisik, lingkungan sosial, lingkungan budaya adalah pola kehidupan dimana setiap personel dapat melaksanakan segala aktivitas kesehariannya dengan menjalin komunikasi yang baik antara kepala sekolah dengan guru, guru dengan guru, dan guru dengan siswa.

Berdasarkan uji koefisien determinasi dalam penelitian ini diperoleh hasil bahwa 36,8\% dari kinerja guru-guru Sekolah Dasar Negeri se-Jalur 8 kecamatan Air Salek Kabupaten Banyuasin dapat dijelaskan oleh supervisi akademik kepala sekolah dan lingkungan kerja dan 63,2\% kinerja guru dipengaruhi oleh faktor lain yang tidak dianalisis dalam penelitian ini diantaranya kepemimpinan kepala sekolah, gaji, faktor personal atau individual meliputi unsur pengetahuan, keterampilan (skill), kemampuan, kepercayaan diri, motivasi, dan komitmen yang dimiliki oleh tiap individu guru, dan lain-lain.

Guru Sekolah Dasar Negeri se-Jalur 8 kecamatan Air Salek Kabupaten Banyuasin sudah seharusnya menunjukkan kemampuan dalam menjalankan tugasnya dengan baik di sekolah serta menggambarkan adanya suatu perbuatan yang ditampilkan dalam selama melakukan aktivitas pembelajaran.

Guru Sekolah Dasar Negeri se-Jalur 8 kecamatan Air Salek Kabupaten Banyuasin harus mendapat kesempatan untuk mengembangkan dirinya sendiri dan juga sekaligus mendapatkan bimbingan dan arahan dari kepala sekolah. Artinya bahwa peningkatan kinerja guru dalam pelaksanaan tugasnya setiap hari sangat ditentukan oleh kepemimpinan dan kemampuan kepala sekolah dan termasuklah didalamnya melalui supervisi akademik.

Penelitian ini semakin menguatkan pendapat atas pentingnya peran supervisi akademik kepala sekolah dan lingkungan kerja untuk meningkatkan kualitas kinerja gurunya. Berkaitan dengan hal tersebut maka dalam rekrutmen kepala sekolah seyogyanya sangat memperhatikan kedua aspek ini agar terseleksi kepala sekolah dengan kemampuan yang optimal. Kepala sekolah adalah salah satu komponen pendidikan yang juga berkaitan secara langsung dalam meningkatkan kinerja

\section{SIMPULAN}

Supervisi akademik kepala sekolah secara individu berpengaruh terhadap kinerja guru Sekolah Dasar Negeri se-Jalur 8 Kecamatan Air salek Kabupaten Banyuasin dengan nilai sig 0,015 lebih kecil dari nilai probabilitas 0,05 dan thitung 2,608 lebih besar dari tTabel 2,04841. Berdasarkan nilai hasil uji koefisien determinasi, 21,3\% dari kinerja guru dapat dijelaskan oleh supervisi akademik kepala sekolah. Lingkungan kerja secara individu berpengaruh terhadap kinerja guru Sekolah Dasar Negeri se-Jalur 8 Kecamatan Air salek Kabupaten Banyuasin dengan nilai sig 0,018 lebih kecil dari nilai probabilitas 0,05 dan thitung 2,512, lebih besar dari tTabel 2,04841. Berdasarkan nilai hasil uji koefisien determinasi, 23\% dari kinerja guru dapat dijelaskan oleh lingkungan kerja. Supervisi akademik kepala sekolah dan lingkungan kerja secara bersamasama berpengaruh terhadap kinerja guru Sekolah Dasar Negeri se-Jalur 8 Kecamatan Air salek Kabupaten Banyuasin dengan Fhitung 7,868 lebih besar dari FTabel 4,12 dan tingkat signifikansi 0,002 lebih kecil dari nilai probabilitas 0,05 . Berdasarkan nilai hasil uji koefisien determinasi, 36,8\% dari kinerja guru dapat dijelaskan oleh supervisi akademik kepala sekolah dan lingkungan kerja. 63,2\% dari kinerja guru dapat dijelaskan oleh sebab-sebab yang lain di luar variabel penelitian misalnya kompetensi, kondisi kerja dan lainlain.

\section{UCAPAN TERIMA KASIH}

Terima kasih penulis ucapkan kepada kepadla sekolah dan guru Sekolah Dasar Negeri se-Jalur 8 Kecamatan Air salek Kabupaten Banyuasin dan semua pihak yang telah membantu selesainya penelitian ini.

\section{DAFTAR PUSTAKA}

Ali, M dan Asrori, M. (2005). Psikologi Remaja Perkembangan Peserta didik. Jakarta: Bumi Aksara.

Aprilyanti, S. (2017). Pengaruh usia dan masa kerja terhadap produktivitas kerja (Studi kasus: PT. Oasis Water International Cabang Palembang). Jurnal Sistem dan Manajemen Industri, 1(2), 68-72. https://core.ac.uk/download/pdf/194456272.pdf

Arep. (2013). Menjadi Guru Profesional. Bandung: Penerbit Rosdakarya.

Arikunto, S. (2006). Supervisi Pendidikan: Terobosan Baru Dalam Peningkatan Kinerja Kepala Sekolah dan Guru. Jakarta: Ar-Ruzz Media.

Arikunto, S. (2010). Supervisi Pembelajaran Dalam Profesi Pendidikan: Membantu Mengatasi Kesulitan Guru Memberikan Layanan Bermutu. Bandung: Alfabeta.

Fatthurrohman. (2011). Supervisi Pendidikan. Yogyakarta: Gava Media. 
Hasanah, M. L., \& Kristiawan, M. (2019). Supervisi Akademik dan Bagaimana Kinerja Guru. Tadbir: Jurnal Studi Manajemen Pendidikan, 3(2), 97-112. http://journal.iaincurup.ac.id/index.php/JSMPI/article/view/1159/pdf

Labich, K. (1993). The New Unemployed. Fortune. March 8. p. 43.

Nitisemito, A. S. (2001). Menjadi Guru Profesional. Bandung: Penerbit Rosdakarya.

Pidarta. (2009). Supervisi dan Peningkatan Mutu Pendidikan. Bandung: Penerbit Alfabeta.

Purbasari, M. (2015). Pengaruh supervisi akademik terhadap kinerja mengajar guru di sekolah dasar. Journal of elementary education, 4(1), 46-52.

https://journal.unnes.ac.id/sju/index.php/jee/article/view/7532

Purwanto, N. (2012). Administrasi dan Supervisi Pendidikan. Bandung: PT. Remaja Rosdakarya.

Putri, H. R. (2016). Pengaruh pendidikan, pengalaman kerja, dan jenis kelamin terhadap produktivitas kerja karyawan bagian produksi CV. Karunia Abadi Wonosobo. Jurnal Pendidikan dan Ekonomi, 5(4), 292300. http://journal.student.uny.ac.id/ojs/ojs/index.php/ekonomi/article/view/4100

Ramadana., \& Wibowo. (2016). Supervisi Pendidikan Dalam Profesi Pendidikan. Bandung: Alfabeta.

Ristiana, N. (2017). Pengaruh Kompensasi, Lingkungan Kerja dan Motivasi Kerja Terhadap Kinerja Guru Tidak Tetap padaSD/MI Kabupaten Kudus. Jurnal Volume 2, Nomor 1 (2017) http://journal.student.uny.ac.id/jurnal/artikel/1610/81/118

Sahertian. (2000). Supervisi Pembelajaran Dalam Profesi Pendidikan: Membantu Mengatasi Kesulitan Guru Memberikan Layanan Bermutu. Bandung: Alfabeta.

Setyana, M. E., Suntoro, I., \& Sumadi, S. (2013). Pengaruh Supervisi Akademik Kepala Sekolah, Komunikasi Interpersonal dan Motivasi Kerja terhadap Kinerja Guru. Jurnal Manajemen Mutu Pendidikan, 1(3). https://www.researchgate.net/profile/manajemenpendidikan/publications

Sugiyono. (2012). Metode Penelitian Pendidikan. Bandung: Cv Alfabeta.

Suhardiman. (2012). Supervisi Pembelajaran Dalam Profesi Pendidikan: Membantu Mengatasi Kesulitan Guru Memberikan Layanan Bermutu. Bandung: Alfabeta.

Sutanto, E. M., \& Ratna, A. (2015). Pengaruh Komitmen Organisasional terhadap Kinerja Karyawan Berdasarkan Karakteristik Individual. BISMA: Jurnal Bisnis dan Manajemen, 9(1), 56-70. https://jurnal.unej.ac.id/index.php/BISMA/article/view/5902

Sutomo. H. (2006). Kepemimpinan dan Supervisi Pendidikan. Jurnal Al-Harokah vol. 63, No. 61.

Uno, H. B. (2016). Teori Motivasi dan Pengukurannya Analisis Dibidang Pendidikan. Jakarta: PT. Bumi Aksara

Wibowo, D. (2016). Pengaruh Supervisi Kepala Sekolah dan Kompetensi Pedagogik Guru Terhadap Kinerja

Guru Sekolah Dasar Neger kecamatan Kersana Kabupaten Brebes. Tesis Program Pasca Sarjana

Universitas Negeri Semarang.

https://www.researchgate.net/profile/manajemenpendidikan/publications.

Yusuf. (2017). Kepemimpinan Kepala Sekolah, Supervisi Akademik dan Motivasi Kerja Dalam Meningkatkan Kinerja Guru.Jurnal Volume 2 No 1 